\title{
A NEW PROCEDURE FOR SELECTIVE RECOVERY OF URANIUM FROM EL-SEBAIYA PHOSPHATE ROCK USING GLUCOSAMINE
}

\author{
W. M. Fathy ${ }^{1}$ and Wlaa Kassab ${ }^{2}$ \\ ${ }^{1}$ Al-Azhar University, Faculty of Engenring., Mining and Petroleum Dept. Nasr City, Cairo, Egypt \\ ${ }^{2}$ Research Sectors, Nuclear Materials Authority, Cairo, Egypt, P.O.Box 530 El Maadi, Cairo, Egypt0 \\ waelfathy12@azhar.edu.eg
}

\begin{abstract}
Glucosamine acting a fundamental role in the extraction process of uranium from El-Sebaiya Phosphate Rock. This process involved selective leaching of uranium (99\%) using 1.12 mole of Glucosamine at $25^{\circ} \mathrm{C}$. The kinetics of the leaching process as well as the reaction mechanism between Glucosamine and uranium have been discussed in details. From the latter, it was found that, the reaction was diffusion controlled and the calculated apparent activation energy was 14 . $78 \mathrm{~kJ} / \mathrm{mole}$.
\end{abstract}

Key words: Glucosamine; Leaching ; uranium ; El-Sebaiya Phosphate Rock



\section{1-INTRODUCTION}

In Egypt, the assured phosphate reserves are estimated about 100 million tons. In 2011, Egyptian production of phosphate rocks is about 6.0 million tons. This means that Egyptian production of phosphate rocks increases by about $590 \%$ from 2000 to 2011. The Egyptian production of phosphate rocks represents about $3.0 \%$ of the world total phosphate rocks production (Jasinski, 2012).

Phosphate ores occur in Egypt in three main provinces, Western desert, Nile valley, and Eastern desert. Added to these are some phosphate- bearing sediments are present in Kurkur and Dungol, Bahariya Oasis, Wadi Qena, Wadi Araba, and Sinai but with limited extent and valueless (E1-Ramly, et al,1970). Phosphoric acid can be manufactured using two principal methods, the thermal process (Singh et al., 2003; IAEA, 2013) and the wet process (European Fertilizer Manufacturers Association 2000, IAEA, 2013). The acid produced by thermal method is extremely pure; however, it is also expensive. The wet process which is based on the acidulation of phosphate ores using any mineral acid is the more popular. Phosphoric acid manufactured using the wet process has many environmental calamities, (Becker, 1989). Among these are the presences of heavy trace elements especially of uranium in El-Sebaiya phosphate rock. During the phosphoric acid wet process, the gypsum formed at acidulation of phosphate with sulfuric acid eq (1), which is formed a large environmental problem around the world on one hand. $\mathrm{Ca}_{10}\left(\mathrm{PO}_{4}\right)_{6} \mathrm{~F}_{2}+10 \mathrm{H}_{2} \mathrm{SO}_{4}+10 \mathrm{n} \mathrm{H}_{2} \mathrm{O} \rightarrow 6 \mathrm{H}_{3} \mathrm{PO}_{4}+10 \mathrm{CaSO}_{4} \cdot \mathrm{nH}_{2} \mathrm{O}+2 \mathrm{HF} \ldots(1)$ 
On the other, Hydrochloric acid and nitric acid with efficiency liberate the co-mineralized radionuclides, specifically uranium, thorium, and radium, at the side of their shorter-lived daughters during leaching process of uranium from phosphate rock and prepared of phosphoric acid equation (2-3).

$\mathrm{Ca}_{10}\left(\mathrm{PO}_{4}\right)_{6} \mathrm{~F}_{2}+20 \mathrm{HNO}_{3} \rightarrow 10 \mathrm{Ca}\left(\mathrm{NO}_{3}\right)_{2}+2 \mathrm{HF}+6 \mathrm{H}_{3} \mathrm{PO}_{4}(2)$

$\mathrm{Ca}_{10}\left(\mathrm{PO}_{4}\right)_{6} \mathrm{~F}_{2}+20 \mathrm{HCl} \rightarrow 10 \mathrm{Ca} \mathrm{Cl}_{2}+2 \mathrm{HF}+6 \mathrm{H}_{3} \mathrm{PO}_{4(3)}$

Generally, many techniques can be used to recover uranium from phosphoric acid di-hydrate and hemihydrate such as solvent extraction tri-butyl butyl phosphate (TBBP) by Singh et al. (2003) and with tributylphosphate (TBP) by using synergism as combining a $\mathrm{D}_{2} \mathrm{EHPA} / \mathrm{TOPO}$ Hurst et al. (1977) ; mixture of DOPPA-TOPO Kreaa and Khalaf (2000). In addition, ion exchange (Parkinson, 1983; Sifniades et al., 1981;Naden et al.,1983) and liquid membrane techniques (El-Hazek and El- Sayed 2003) also used to recover of uranium from phosphoric acid.

To avoid the mentioned environmental problem produced via recovery of uranium from phosphoric acid, there are many efforts to recover of uranium from phosphate rock before acidulation, involves leaching with sodium carbonate $\left(\mathrm{Na}_{2} \mathrm{CO}_{3}\right)$ and sodium bicarbonate $\left(\mathrm{NaHCO}_{3}\right)$ solutions (Shlewit and Alibrahim,2008) . Amin and Ghazala(2014) have been succeed to recoverof uranium from El-Sebaiya phosphate rock using the fermented media of the Penicillium Simplicissimum with leaching efficiency of $64 \%$.The choice of leaching reagant depends upon the composition of phosphate ore and the economical and environmental factors such as cost of leaching agent, solubility of contaminants, recovery methods and tailings management (Shlewit and Alibrahim,2008).

In this context, several studies have previously been proven the stability of reaction between chitosan and chitin as an absorbance for uranium (Ahmed et al, 2014; Wang et al., 2009, Xu et al., 2013; Huang et al, 2016). (Sun et al., 2018) also reported ,that the uranium(VI) in radioactive wastewater was effectively adsorbed on phosphate rock and chitosan modified phosphate rock. Glucosamine $\left(\mathrm{C}_{6} \mathrm{H}_{13} \mathrm{NO}_{5}\right)$ is an amino sugar and a prominent precursor in the biochemical synthesis of glycosylated proteins and lipids. Glucosamine is part of the structure of the polysaccharides, chitosan, and chitin. Glucosamine is one of the most essential monosaccharide derivatives (pigman et al., 1980). It is produced commercially by the hydrolysis of crustacean exoskeleton by fermentation of a grain such as corn or wheat. In this context the present work was design to investigate the selective dissolution of uranium from Sebaiya phosphate rock using glucoseamine. The work then shifted to recover of leached uranium and purified the obtained product of yellow cake.

\section{2- EXPERIMENTAL}

\subsection{Materials}

A collected technological sample weighing about $5 \mathrm{~kg}$ from Sebaiya phosphate rock, were prepared by the quartering method and ground to $0.250 \mathrm{~mm}$ particle size with the aid of a Pascall disc coning and mill.

\subsection{Leaching procedures}

\subsubsection{Glucosamine leaching of uranium}

Several leaching experiments for uranium have actually been performed using glucosamine to optimize the relevant leaching factors. In these experiments, a suitable weight of the working Sebaiya phosphate rock was mixed with a suitable volume of glucosamine have different concentrations. The slurry was then agitated for a fixed time at a certain temperature after which the treated slurry was filtered and the residue left behind was thoroughly washed with distilled water and both filtrate and washing were made up to volume before analysis.

\subsection{Analytical procedures}

Proper quartering of the technological sample was performed after its grinding to $0.250 \mathrm{~mm}$ to obtain a representative sample which was subjected to complete chemical analysis of both major and trace elements content. (Shapiro and Brannock, 1962). Whereas $\mathrm{SiO}_{2}, \mathrm{Al}_{2} \mathrm{O}_{3}, \mathrm{TiO}_{2}$ 
and $\mathrm{P}_{2} \mathrm{O}_{5}$ were determined using spectrophotometic methods, the contents of $\mathrm{Na}$ and $\mathrm{K}$ were determined by photometric technique. Total $\mathrm{Fe}$ as $\mathrm{Fe}_{2} \mathrm{O}_{3}, \mathrm{MgO}$ and $\mathrm{CaO}$ were determined

by titration methods. The loss on ignition (L.O.I) was determined gravimetrically. The estimated error for major cons tuents is not more than $+1 \%$.

To follow the leaching and recovery efficiencies, the different stream solutions were subjected to $U$ analysis. The latter achieved by the oxidimetric titration method against ammonium metavanadate after its reduction (Mathew et al. ,2009). Finally, the obtained products have been qualitatively analyzed using ESEM-EDX (Environmental Scanning Electron Microscopy/Energy Dispersive X-ray Spectroscopy, Philips XL 30) together with wet chemical analyses. Infra-red spectra ( $\mathrm{KBr}$ disk ) of glucosamine before and after reaction with uranium were obtained using Book Company, New York Spectrometer.

\section{3- RESULTS AND DISCUSSION}

\subsection{Chemical composition of the working technological sample}

The complete chemical analysis of the working technological of El- Sebaiya phosphate ore sample is given in table (1) as well as its metal values of U. From the latter, it is clearly evident that besides the high level of the loss on ignition $10 \%$, it contains a high Ca content metal which exists as carbonate minerals ; a matter that reflects a high carbonate content. As a matter of fact, the presence of low silica content and iron has been behind the choice of glucosamine as a leaching agent of uranium selectively in order to avoid the preparing of phosphoric acid in classical uranium leaching procedures from phosphoric acid.

Table (1): The chemical analysis of the working ore phosphate sample ; El- Sebaiya ore sample

\begin{tabular}{|c|c|c|c|}
\hline Component & wt.\% & Component & wt.\% \\
\hline $\mathrm{SiO}_{2}$ & 8.35 & $\mathrm{CaO}$ & 38.98 \\
\hline $\mathrm{TiO}_{2}$ & 0.18 & $\mathrm{~K}_{2} \mathrm{O}$ & 0.2 \\
\hline $\mathrm{Al}_{2} \mathrm{O}_{3}$ & 1.43 & $\mathrm{P}_{2} \mathrm{O}_{5}$ & 33.66 \\
\hline $\mathrm{Fe}_{2} \mathrm{O}_{3}$ & 4.12 & ${ }^{2}$ L.O.I .( $\left.1000^{0} \mathrm{C}\right)$ & 10 \\
\hline $\mathrm{MgO}$ & 0.85 & $\mathrm{U}$ & 0.010 \\
\hline $\mathrm{Na}_{2} \mathrm{O}$ & 1.00 & total & 98.77 \\
\hline
\end{tabular}

*L.O.I. = loss on ignition

\subsection{Results of chemical processing}

\subsubsection{Effect of glucosamine concentration}

The effect of glucosamine concentration was studied between 1 and 1.13 mole, while the other leaching factors were fixed at $0.250 \mathrm{~mm}$ particle size, an hour agitation time, $25^{\circ} \mathrm{C}$ leaching temperature and solid-liquid (S/L) ratio; 1/4. Highest leaching efficiencies of uranium given in table (2) was $78 \%$ which indicate that the best concentration of glucosamine is 1.12 moles for about $(200 \mathrm{~g} / \mathrm{l})$. Higher concentrations of glucosamine 1.13 mole did not markedly affect the uranium leaching efficiency.

The obtained leach liquors were then analyzed for the uranium value to calculate its leaching efficiency percent according the equation: 
$\%$ Leaching efficiency $=$

Metal content in the leach liquor

Original metal content in the ore

$\times 100$

In this regard, a suggested mechanism of uranium with glucosamine according to (Ahmed et al.,2014) as shown below Scheme (1) . On other hand, from Fig.(1) infrared spectrum indicate that; the band observed at $3278 \mathrm{~cm}^{-1} \mathrm{~N}-\mathrm{H}$ (primary amine ) and $\mathrm{O}-\mathrm{H}$ alcoholic in glucosamine before reaction with uranium were shifted to $3328 \mathrm{~cm}^{-1}$. The carbonyl group for glucosamine was at $1636 \mathrm{~cm}^{-1}$ observed. It is important to mention herein that, the $\mathrm{pH}$ of glucosamine solution is 6.4 which prevent to soluble of either phosphate or calcium . ( Pinto et al., 2011)


Scheme (1): Suggested mechanism of uranium with glucosamine according to (Ahmed et al., 2014)

Table (2): Effect of glucosamine concentration upon uranium leaching efficiencies from El-Sebaiya phosphate rock sample

\begin{tabular}{|c|c|}
\hline Glucosamine concentration, mole & Uranium Leaching efficiency, \% \\
\hline 1.00 & 60 \\
\hline 1.10 & 63 \\
\hline 1.11 & 65 \\
\hline 1.12 & 78 \\
\hline 1.13 & 79 \\
\hline
\end{tabular}




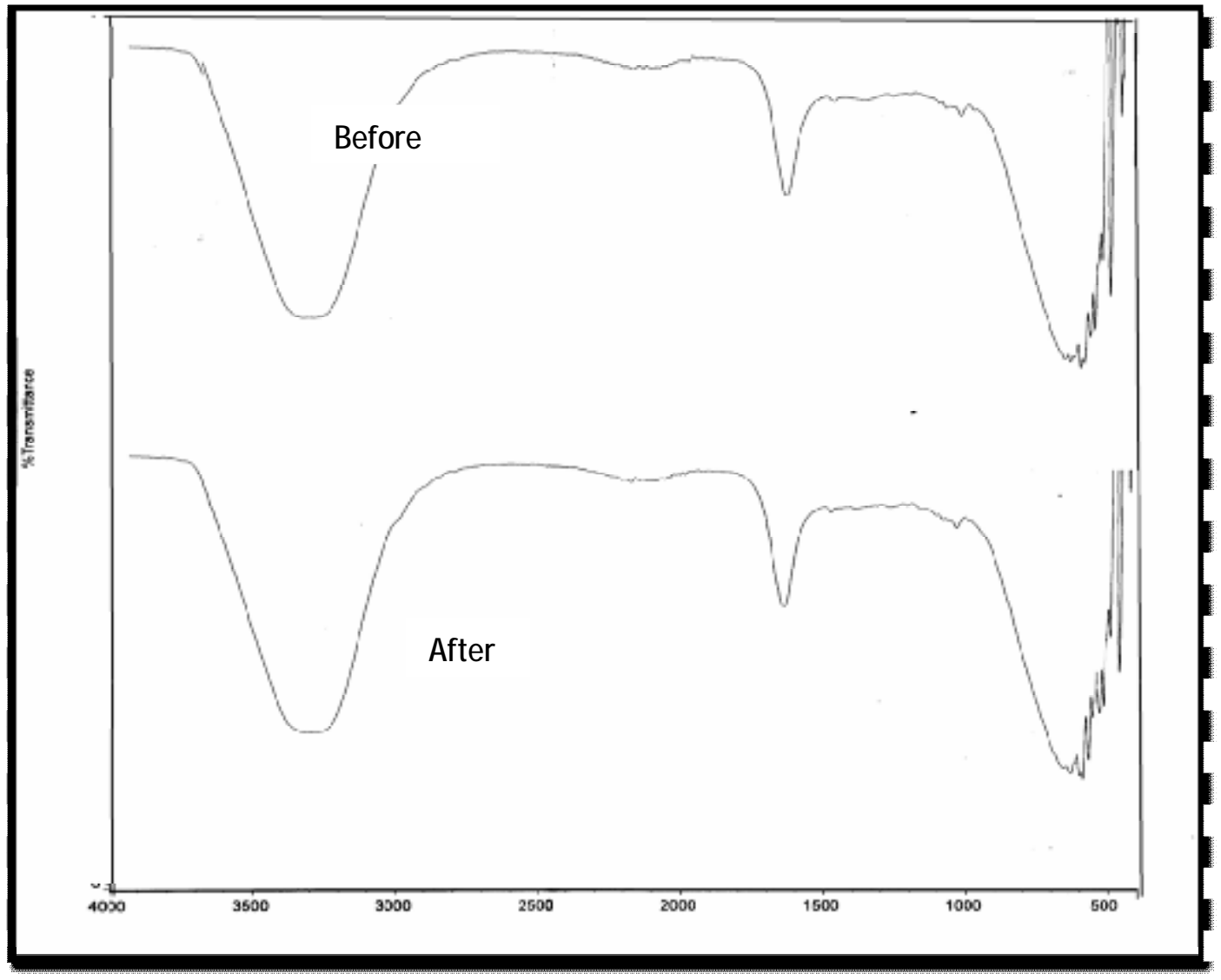

Fig.(1): Infra-red spectra of glucosamine before and after reaction with uranium

\subsubsection{Effect of agitation Time}

The effect of leaching time upon U leaching efficiency was studied in the range from 60 to 120 minute while the other leaching conditions were fixed at 1.12 mole glucosamine concentration, $0.25 \mathrm{~mm}$ particle size ore material, a leaching temperature of $25^{\circ} \mathrm{C}$ and 1:4 solid / liquid ratio. The obtained data shown in table (3) revealed that a high uranium leaching efficiency exceeding $99 \%$ occurs at $120 \mathrm{~min}$.. Therefore, it can be concluded that 120.min. are adequate to almost complete $\mathrm{U}$ leaching using 1.12 mole glucosamine concentration .

Table (3): Effect of leaching time upon uranium leaching efficiencies from El-Sebaiya phosphate rock sample

\begin{tabular}{|c|c|}
\hline Time/minutes & Uranium Leaching efficiency, $\%$ \\
\hline 60 & 78 \\
\hline 70 & 85 \\
\hline 80 & 91 \\
\hline 100 & 95 \\
\hline 120 & 99 \\
\hline
\end{tabular}




\subsubsection{Effect of the solid/liquid ratio}

The effect of the solid/liquid ratio upon uranium leaching efficiency was studied between $1 / 2$ and 1/4. In these experiments, the fixed leaching conditions involved -200 mesh size material $(0.25 \mathrm{~mm}), 1.12$ mole glucosamine concentrations for $120 \mathrm{~min}$. agitation time at $25^{\circ} \mathrm{C}$ as leaching temperature. From the obtained leaching efficiencies given in table (4), a solid ratio of 1/4 would be considered as optimum at which the attained complete leaching efficiency of uranium.

Table (4): Effect of solid/liquid ratio upon uranium from El-Sebaiya phosphate rock sample

\begin{tabular}{|c|c|}
\hline Solid/liquid ratio & Uranium Leaching efficiency, \% \\
\hline $1 / 2$ & 85 \\
\hline $1 / 3$ & 97 \\
\hline $1 / 4$ & 99 \\
\hline
\end{tabular}

From the above studied leaching factors of uranium from El-Sebaiya phosphate rock sample, it can be concluded that the optimum leaching conditions for dissolving about $99 \%$ of $U$ would be summarized as follows:

Grain size

Acid concentration

Leaching time

Leaching temperature

Solid/liquid ratio
$0.250 \mathrm{~mm}$.

1.12 mole $(200 \mathrm{~g} / \mathrm{L})$

120 minute

$25^{\circ} \mathrm{C}$.

$1 / 4$

\subsection{Kinetics of leaching process}

3.3.1.Effect of leaching time on the dissolution of uranium at different temperatures

3.3.1.Effect of leaching time on the dissolution of uranium at different temperatures

Fig. $(2)$ presents the effect of the reaction temperature on the uranium leaching rate in the range of $25^{\circ} \mathrm{C}-85^{\circ} \mathrm{C}$ under conditions of -200 mesh size particles, $200 \mathrm{~g} / \mathrm{L}$ (1.12mole). The results show that the leaching rate of uranium increases as the time increases. In order to obtain the kinetic equation and the apparent activation energy for the dissolution of uranium, the experimental data given in (Fig.2) were correlated to various kinetic models for solid-liquid reactions. 


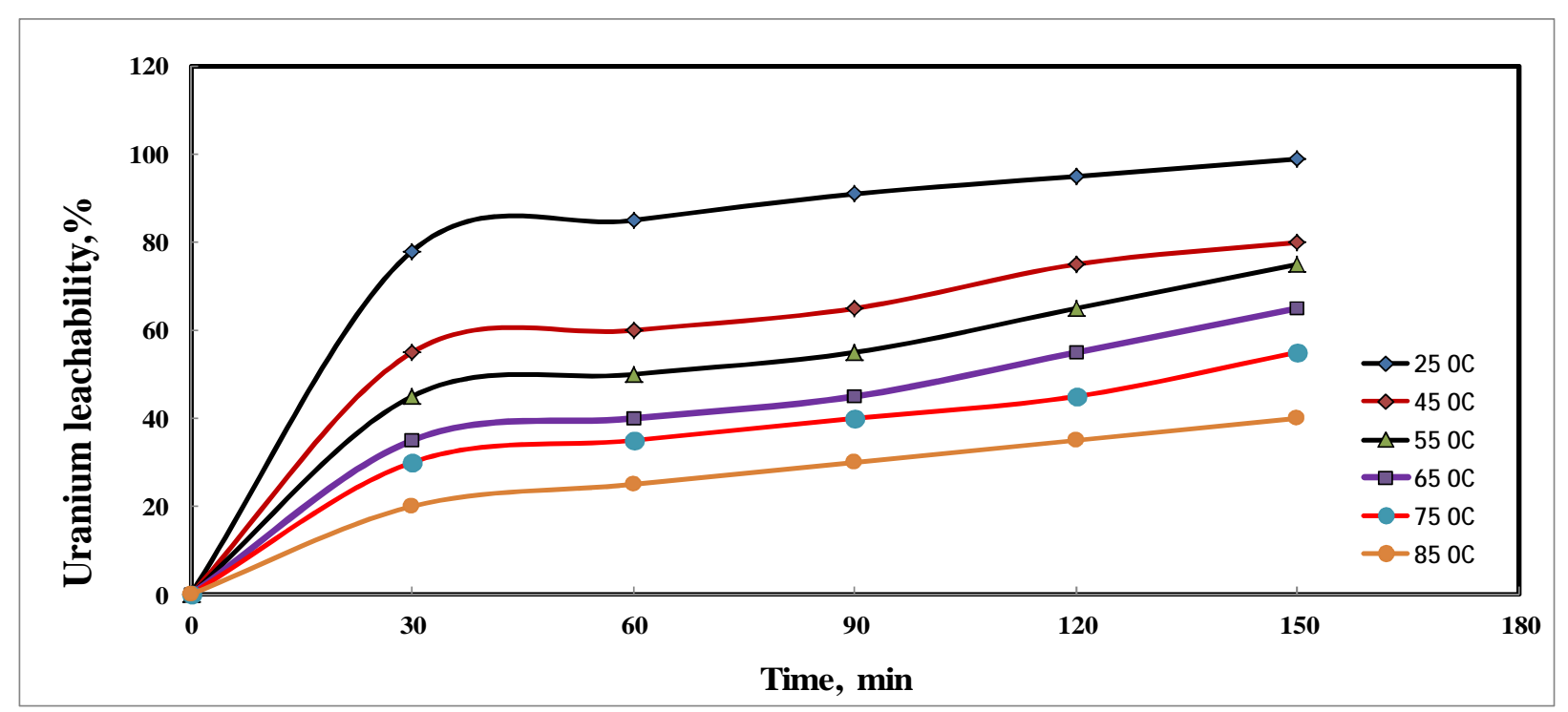

Fig.(2 ): Effect of leaching time upon uranium dissolution at different temperature.

\subsubsection{Application of leaching kinetic models}

The un-reacted shrinking-core model is the most commonly used mathematical model to describe the heterogeneous reactions like mineral leaching from ores. In the solid-liquid phase reactions, the rate of reaction is controlled by the following steps: liquid-film diffusion (mass transfer), solid or product layer diffusion, and surface reaction or chemical reaction. One or more of these factors might control the rate of the reaction (Levenspiel 1999). Amongst the three controlling mechanism the liquid-film diffusion resistance is eliminated or minimized by effective stirring.

In order to determine the type of leaching mechanism prevalent for the uranium ore, the obtained results from (Fig.2) were considered. These results were analyzed by using the following kinetic rate Eqs. (1) and ( 2 ) in literature review(Levenspiel 1999).].

Reaction rate expression controlled by the surface chemical reaction:

$\left[1-(1-\mathrm{x})^{1 / 3}\right]=\mathrm{K}_{\mathrm{c}} \mathrm{t}$

Reaction rate expression controlled by the diffusion through the ash or product layer:

$\left[1-3(1-x)^{\frac{2}{3}}+2(1-x)\right]=K_{d} t$

\section{Where}

$\mathbf{X}$ is the conversion fraction of solid particle.

$\mathbf{k}_{\mathbf{c}}$ is the rate constant $\left(\mathrm{min}^{-1}\right)$ for chemical reaction.

$\mathbf{k}_{\mathbf{d}}$ is the apparent rate constant $\left(\mathrm{min}^{-1}\right)$ for diffusion through the product layer.

tis the reaction time.

The results of calculating 1- $(1-\mathrm{X})^{1 / 3}$ at different leaching times and temperatures are shown in Figures (3and 4) show the result of plotting 1- (1- $)^{1 / 3}$ and $1-3\left(1-\frac{1}{1}\right)^{2 / 3}+2(1-\bar{I})$ as a function of time at different leaching temperatures. The values of the reaction rate constantsK were determined from the slope ( $\mathrm{x}$ factor) of the straight line of the relation between kinetic model and time. 


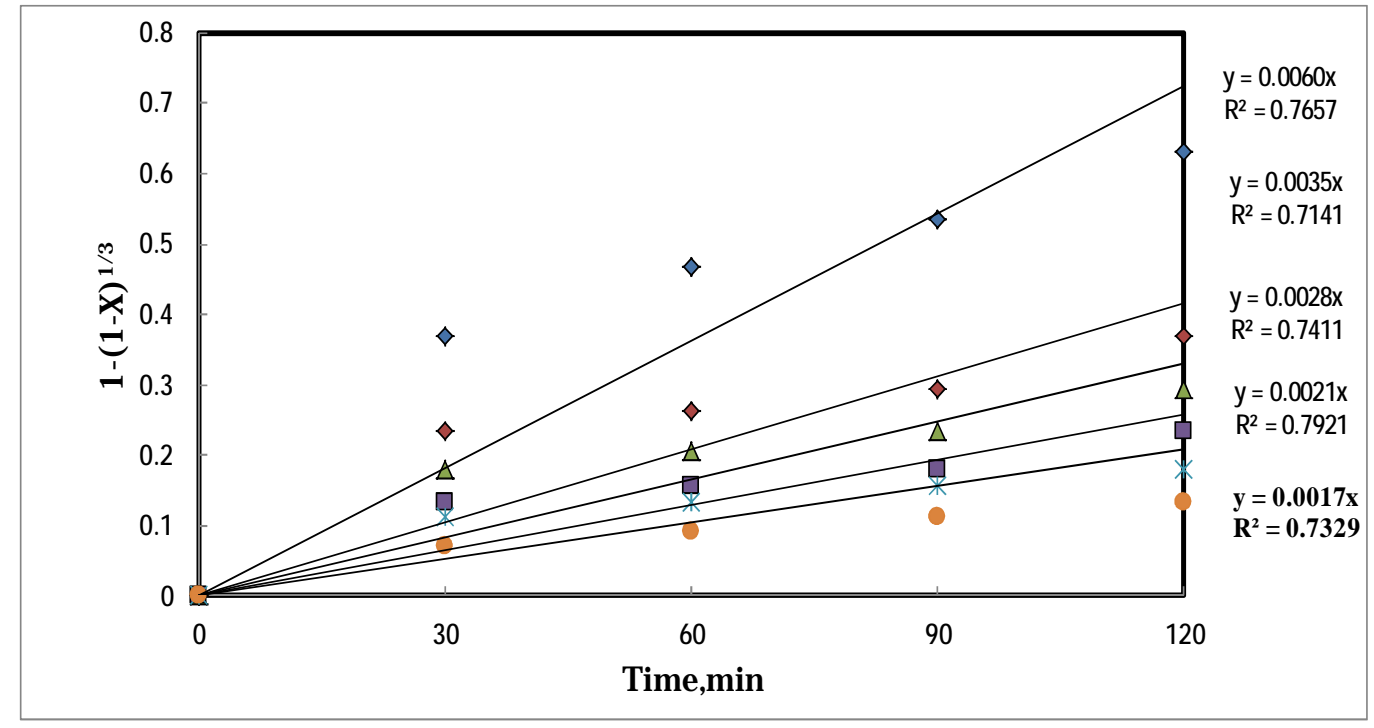

Fig.(3): plot of 1-(1-x) ${ }^{1 / 3}$ versus time for different temperatures.

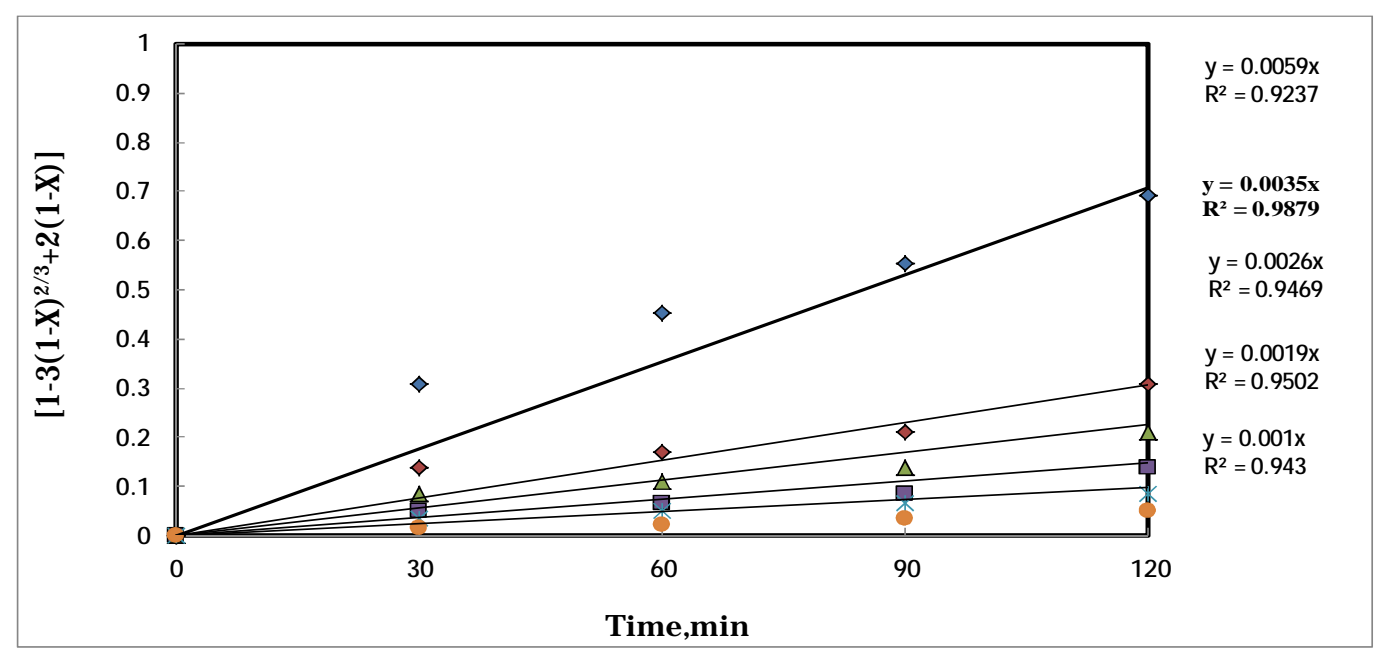

Fig.(4): plot of [1-3(1-x) $\left.{ }^{2 / 3}+2(1-x)\right]$ versus time for different temperatures.

The $\mathrm{R}^{2}$ values mean the extent of fitting between the experimental data and the predicted one. The best fit has $\mathrm{R}^{2}$ of nearly 1.0 . The $\mathrm{k}_{\mathrm{c}}$ values vary in the rage of $0.0017-0.006 \mathrm{~min}^{-1}$ while the $\mathrm{k}_{\mathrm{d}}$ were between 0.0001 and $0.00059 \mathrm{~min}^{-1}$. The $\mathrm{R}^{2}$ values for $\mathrm{k}_{\mathrm{d}}$ were 0.943 to 0.9237 while for $k_{c}$ it was in the range of $0.7329-0.7657$. Based on the $\mathrm{R}^{2}$ values it can be inferred that the predominant dissolution mechanism of uranium from the phosphate sample is diffusion controlled only.

\subsubsection{Calculation of the activation energy}

The relation between the logarithmic values of the reaction rate constants $\mathrm{K}_{\mathrm{d}}$ and the reciprocal of the absolute leaching temperatures are plotted against the reciprocal of the absolute reduction temperature according to the Arrhenius equation that shown in Fig. ( 5 )Levenspiel 1999).]. 


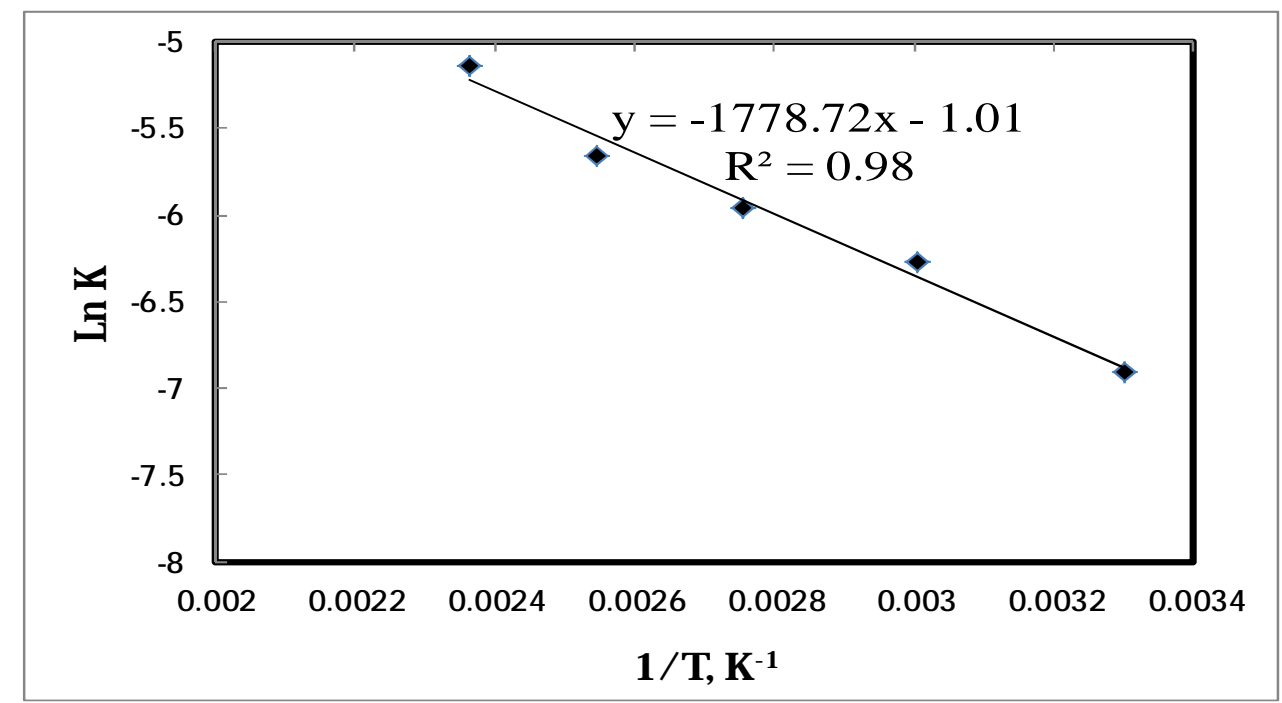

Fig.(5 ): Plot of $\operatorname{LnK}_{d}\left(\mathrm{~min}^{-1}\right)$ against reciprocal of absolute temperature $\left(\mathrm{K}^{-1}\right)$.

The activation energy of the reaction can be calculated using the following equation:

$$
\begin{gathered}
\mathrm{K}=\mathrm{A} \exp (-\mathrm{Ea} / \mathrm{RT}) \ldots \ldots \\
\mathrm{Lnk}=-\mathrm{Ea} / \mathrm{Rg}(1 / \mathrm{T})+\mathrm{LnA} .
\end{gathered}
$$

\section{Where}

$\mathrm{K}$ is a reaction rate constant, recovery (conversion fraction) in $\min ^{-1}$.

$\mathrm{A}$ is the frequency factor, constant $\mathrm{min}^{-1}$.

Ea is the apparent activation energy $\mathrm{kJmol}^{-1}$.

$\mathrm{Rg}$ is the universal gas constant $=8.314 \mathrm{Jk}^{-1} \mathrm{~mol}^{-1}$.

$\mathrm{T}$ is the absolute reaction temperature " $\mathrm{k}$.

From figure (5) the activation energy (Ea) was calculated as follow:

$$
\text { Slope }=\frac{\text {-Ea }}{\mathbf{F} \mathbf{g}}
$$

For reaction rate expression controlled by the diffusion $\mathrm{e}$

Equation, $\quad y=\mathbf{- 1 7 7 8 . 7 2 x}-\mathbf{- 1 . 0 1}$

$$
-1778.27 \mathrm{x}=\frac{- \text { Ea }}{\mathbf{8}} \text {. 포14 }
$$

$\mathrm{Ea}=[-1778.27 *-8.314]=14788.28 \mathrm{Jmol}^{-1}=14.78828 \mathrm{~kJ} / \mathrm{mol}$

$$
\text { : EII }=14.78828 \mathrm{~kJ} / \mathrm{mol}
$$

The apparent activation energy (Ea) was calculated from the slope of straight line obtained to be $14.788 \mathrm{~kJ} / \mathrm{mole}$ for diffusion controlled reaction models. Based on the (Ea) values, it can be inferred that the predominant dissolution mechanism of uranium from the phosphate sample is diffusion controlled only. Hence, all resulted data are found to fit the shrinking core model with chemical reaction as a rate determining step [ Levenspiel( 1999); Crundwell (2013); Yuan (2018)] Also, shrinking core model (SCM) with a mixed chemical and diffusion control mechanisms was suggested in the dissolution kinetics of many ores [ Silva (2004) Souza et al., (2007) Tavakoli et al., (2017)] 


\subsection{Recovery of uranium}

To recover uranium from El-Sebaiya phosphate rock pregnant solution was prepared by applying the above mentioned optimum leaching conditions upon one $\mathrm{kg}$ of the provided El-Sebaiya phosphate rock which has revealed the assay of $0.049 \mathrm{~g} / \mathrm{L}$ of uranium. Uranium was recovered via evaporation process to obtain directly the orange cake namely; $\mathrm{UO}_{3}$. The obtained hydrated $\mathrm{UO}_{3}$ was then washed and dried to be ascertained by the qualitative ESEM analysis as shown in Fig. (6). On the other hand, the obtained pure uranium concentrate revealed U content of $83 \%$ recorded by the quantitative chemical analysis.

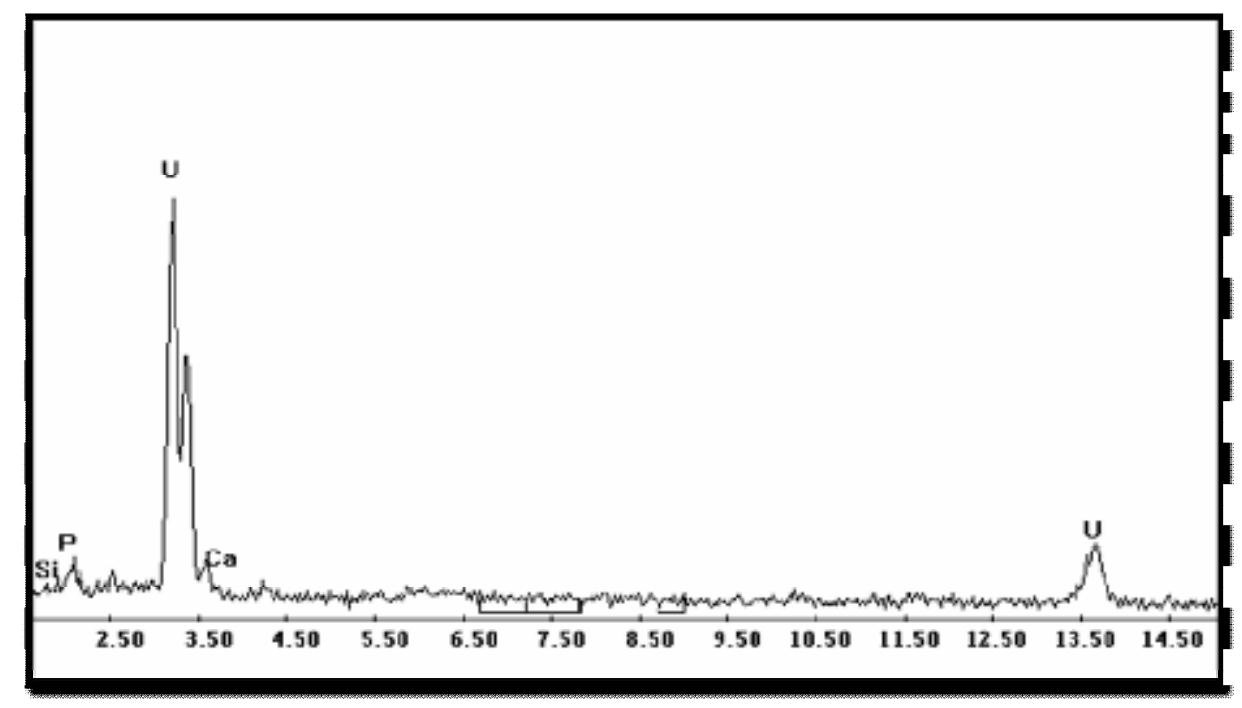

Fig.(6): ESEM- EDX analysis for the identification UO3 .

\section{4-CONCLUSIONS}

For selective recovery of uranium from El-Sebaiya Phosphate Rock, glucosamine has been applied. The optimum leaching conditions involved 1.12 mole of glucosamine, $2 \mathrm{~h}$ agitation time, room temperature at $\mathrm{S} / \mathrm{L}$ ratio of $1: 4$. Kinetics of the leaching process have been proved to be diffusion controlled and the calculated apparent activation energy was $14.78828 \mathrm{~kJ} / \mathrm{mol}$. The work was then shifted to separate uranium selectively from the prepared leach liquor via evaporation process to obtain directly the orange cake namely; $\mathrm{UO}_{3}$.

\section{REFERENCES}

1. Ahmed, S.H., El Sheikh, E.M., Morsy,A.M. (2014). Potentiality of uranium bio sorption from nitric acid solutions using shrimp shells. Journal of Environmental Radioactivity 13 , 120 127.

2. Amin, M.M., Ghazala, R.A. (2014). A Potentiality of uranium solubilization from phosphate rock sample using mixture of organic acids of fermented media. An Indian Journal, 9(6) pp. 212-217.

3. Becker, P. (1989). Phosphates and phosphoric acid: raw materials, technology, and economics of the wet process. 2nd Edition, New York Marcel Dekker, Inc..

4. Crundwell, F.K. (2013). The dissolution and leaching of minerals. Mechanisms, myths and

5. Misunderstandings, Hydrometallurgy. 139. pp. 132-148.

6. El-Hazek, N.T., El- Sayed, M.S. (2003). ,Direct uranium extraction from dihydrate and hemi-dihydrate wet process phosphoric acids by liquid emulsion membrane . Radio analytical and Nuclear Chemistry 257(2). pp. 347-352.

7. E1-Ramly, M.F., Ivanov, S.S. and Kochin,G.G. (1970) Generalization of geological data on hard minerals". Geol. Surv.of Egy.Rep. pp. 21-24.

8. European Fertilizer Manufacturers Association (2000). Production of phosphoric acid. Booklet No. 4 of 8, Belgium. 
9. Huang, G.L., Zou, L.X., Su, Y. et al. (2016). Adsorption of uranium (VI) from aqueous solutions using cross-linked magnetic chitosan beads. Journal of Radioanalytical\& Nuclear Chemistry, 307. pp. 1135-1140.

10. Hurst, F., Arnold, W., Ryon, A. (1977). Recovering uranium from wet process phosphoric acid" Chemical Engineering, 84(1). Pp. 56-57.

11. International Atomic Energy Agency. (2013). Radiation Protection and Management of Norm Residues in the Phosphate Industry". Safety Reports Series No.78, Vienna.

12. Jasinski, S.M. (2012). Phosphate Rock. USGS p. 119.

13. Krea, M., Khalaf, H. (2000). Liquid-liquid extraction of uranium and lanthanides from phosphoric acid using a synergistic DOPPA-TOPO mixture. Hydrometallurgy 58(3). Pp. 215-225.

14. Pigman, W.W., Horton, D., Wander, J.D. (1980). The Carbohydrates. Vol IB. New York: Academic Press. ISBN 9780125563512. pp. 727-728.

15. Levenspiel, O. (1999). Chemical reaction engineering, John Wiley\&Sons New York. Chichester Weinheim Brisbane Singapore Toronto . p. 684 .

16. Mathew, K.J., et al. (2009). Uranium assay determination using Davies and Gray titration Proceedings of The Eighth International Conference on Methods and Applications of Radioanalytical Chemistry (Marc Viii) Kailua- Kona, Hawaii.

17. Naden, D., Rowden, G., Juni, D., Wilson, D. (1983). Development and application of solvent extraction resin ion exchange (RIP) and liquid membrane processes for uranium recovery". Advances in Uranium Ore Processing and Recovery from Non-Conventional-Resources, IAEA, Vienna.

18. Parkinson, G. (1983). Liquid membranes. Chem. Eng., 22. pp. 22-27.

19. Pinto, O.A., Tabaković, A. , Goff, T.M., Liu, Y., and Adair, J.H. (2011). Calcium Phosphate and Calcium Phosphosilicate Mediated Drug Delivery and Imaging. Fundamentals and Applications, Fundamental Biomedical Technologies 5. pp. 713-718.

20. Shapiro, L., Brannock, N. (1962). Rapid Analysis of Silicate, Carbonate and phosphate Rocks, U.S. Geol. Surv. Bull.,114 A, 65.

21. Sifniades, S., Largman, T., Tunik, A. , Koff, F. (1981). Recovery of uranium from phosphoric acid by means of supported liquid membranes. J. Hydro., 7:201-212.

22. Shlewita H, Alibrahim M 2008, Recovery of uranium from phosphate by carbonate solutions Journal of Radioanalytical and Nuclear Chemistry, Vol. 275, 1. pp. 97-100.

23. Singh, H., Mishra, S., Vijayalakshmi, R. (2003) Uranium extraction from partially neutralised and diluted phosphoric acid using a synergistic organophosphorous solvent mixture. Hydrometallurgy 70 (1-3). Pp. 197-203.

24. Silva, G.A. (2004) Relative importance of diffusion and reaction control during the bacterial and ferric sulphate leaching of zinc sulphide, Hydrometallurgy, 73. pp. 313-324.

25. Souza, A.D., Pina, P.S., Leo, V.A., Silva, C.A., Siqueira, P.F. (2007). The leaching kinetics of zinc sulphide concentrate in acid ferric sulphate. Hydrometallurgy 89. pp.72-81.

26. Sun, Z., Chen, D., Chen, B., Kong, L., Su, M. (2018). Enhanced uranium(VI) adsorption by chitosan modified phosphate rock. Colloids and Surfaces A: Physicochemical and Engineering Aspects 547. pp. 141-147.

27. Tavakoli, H.Z., Abdollahy, M., Ahmadi, S.J., Darban, A.K. (2017). Kinetics of uranium bioleaching in stirred and column reactor. Miner Eng 111. pp. 36-46.

28. Wang, G.H., Liu, J.S., Wang, X.G. (2009). Adsorption of uranium(VI) from aqueous solution onto cross-linked chitosan .Journal of Hazardous Materials, 168. pp. 1053-1058.

29. Xu J S, et al 2013,Adsorption of uranium(VI) from aqueous solution by di-ethylenetriaminefunctionalized magnetic chitosan. Journal of Radio analytical \& Nuclear Chemistry, 298. pp. 1375-1383.

30. Yuan, F. (2018). Study on kinetics of Fe (II) oxidized by air in $\mathrm{FeSO}_{4}-\mathrm{H}_{2} \mathrm{SO}_{4}$ solutions. Miner Eng. 121. pp.164-168. 